\title{
“PERAN PANCASILA PADA ERA GLOBALISASI" KAJIAN TERHADAP PANCASILA DAN FENOMENA LGBT (LESBIAN,GAY,BISEXUAL,TRANSGENDER) DI INDONESIA
}

Oleh :

\author{
Wawan Setiawan, Yudhitiya Dyah Sukmadewi
}

\begin{abstract}
ABSTRAC
LGBT phenomenon into a "hot issue" in the international and national levels. LGBT phenomenon in Indonesia would result in the pros and cons of the community. Various groups of people, mainly from religious groups opposed to the existence of the phenomenon. On the other hand, there are also groups that support the LGBT community in Indonesia, the main actors and human rights activists (Human Rights). Most LGBT people found contrary to the noble values of Pancasila, but on the other hand assumes that actors LGBT community is not sexual deviation, and shall have the rights and equality. It is thus necessary to do a study to determine the response of the people of Indonesia respond to the phenomenon of LGBT specifically in this case the younger generation, as well as to determine whether or not the phenomenon of LGBT contrary to the basic values of Pancasila as the State Indonesia.
\end{abstract}

Keywords: Pancasila, Norm, LGBT

\section{A. PENDAHULUAN}

\section{Latar Belakang}

Fenomena Lesbian, Gay, Bisexual and Transgender (LGBT) merupakan fenomena yang menjadi perdebatan di kalangan masyarakat internasional maupun nasional. Secara garis besar, LGBT merupakan bentuk menyukai sesama jenis. Tidak sedikit pula negaranegara di dunia yang telah mendukung perilaku LGBT dan melegalkan perkawinan sesame jenis. Bahkan ada pejabat di beberapa Negara yang melakukan perkawinan sesama jenis seperti Perdana Menteri Luksemburg Xavier Battel yang menikah dengan pasangannya sesama jenis pada tahun 2015. Kemudian pada tahun 2010 Perdana Menteri Islandia, Johanna
Sigurdardottir melakukan perkawinan dengan pasangan sesama jenisnya.

Pada tahun 2015, fenomena LGBT mulai menjadi "isu hangat" di Indonesia dan tentunya mengakibatkan pro dan kontra dari masyarakat. Mulai pula bermunculan public figure yang terindikasi menyukai sesama jenis seperti kasus artis Saipul Jamil yang melakukan pencabulan terhadap fans-nya sesama jenis pada tahun 2016. Kemudian pada tahun 2013 salah satu artis Indonesia Dena Rahman mengumumkan perpindahan gender dari semula laki-laki menjadi wanita. Kabar tersebut menjadi perdebatan dan disoroti oleh banyak kalangan.

Berbagai kelompok masyarakat, utamanya dari kelompok agama menentang keras adanya fenomena tersebut. Disisi lain, tidak sedikit pula 
kelompok masyarakat yang mendukung adanya LGBT di Indonesia, bahkan ada yang mengusulkan agar pemerintah segera membuat kebijakan untuk mengakomodasi kepentingan para penganut LGBT. Pihak yang menentang tersebut berpendapat bahwa LGBT merupakan perilaku menyimpang dan bertentangan dengan nilai-nilai luhur Pancasila. Terlebih lagi, perilaku LBGT sedang "trend" di kalangan generasi muda sehingga dapat memberikan pengaruh negatif, terutama bagi masa depan mereka. Bagi kelompok masyarakat yang mendukung LBGT, perilaku tersebut sah-sah saja untuk dilakukan sebagaimana manusia normal pada umumnya. Justru Pemerintah harus mengakomodasi kepentingan kaum LBGT agar setara dengan masyarkat lainnya atas dasar persamaan hak asasi manusia.

Pada dasarnya, perilaku LBGT sudah lama ada di Indonesia, namun tidak secara terang-terangan muncul di lingkungan masyarakat, mengingat respon masyarakat cenderung negatif menanggapi hal tersebut. Namun, setelah isu LBGT menjadi perbincangan dunia dan beberapa Negara mendukung legalisasi hak kaum LBGT, maka kaum LBGT di Indonesia ikut mendesak Pemerintah untuk melegalkan LBGT melalui pembentukan Peraturan
Perundang-undangan yang mengatur hak-hak kaum LBGT. Saat ini, kaum LBGT-pun secara terang-terangan berani untuk menyatakan sikap di hadapan umum maupun di lingkungan masyarakat. Menurut survey yang dilakukan oleh Freedom to Marry Organization pada tahun 2014, bahwa telah ada 22 negara dari 204 negara yang telah diakui secara de facto oleh PBB yang melegalkan perkawinan sejenis diseluruh wilayah negaranya.

\section{Rumusan Masalah}

Berdasarkan latar belakang masalah yang telah dikemukakan diatas, Penulis merumuskan beberapa permasalahan yang akan dibahas dalam penelitian ini, yaitu :

a. Bagaimana respon masyarakat khususnya generasi muda menanggapi fenomena LGBT yang terjadi di Indonesia?

b. Apakah fenomena LGBT yang terjadi di Indonesia bertentangan dengan nilai Pancasila sebagai dasar negara?

\section{Tujuan Penelitian}

Adapun tujuan dari penelitian ini, yaitu :

a. Untuk mengetahui bagaimana respon masyarakat khususnya generasi muda menanggapi 
fenomena LGBT yang terjadi di Indonesia

b. Untuk menganalisa apakah fenomena LBGT yang terjadi di Indonesia bertentangn dengan nilai Pancasila sebagai dasar Negara

\section{B. BAB II TINJAUAN PUSTAKA}

\section{Kajian Teori}

Dalam penelitian ini, Penulis mendasarkan pada teori yang relevan dengan kajian penelitian, yaitu Teori Piramida Berjenjang (Stuffenbau Theory) Oleh Hans Kelsen Kedudukan pancasila sebagai dasar negara merupakan kedudukan yang fundamental. Secara garis besar, teori tersebut digambarkan melalui gambar segitiga yang menyerupai piramida dan memiliki jenjang yang berbeda-beda. Pada jenjang pertama, Pancasila berkedudukan paling tinggi sebagai grundnorm (norma dasar). Artinya pancasila menjiwai seluruh bidang kehidupan manusia dan dijadikan sebagai pedoman dalam penyelenggaraan pemerintahan.

Pada jenjang dibawahnya merupakan UUD 1945 sebagai konstitusi NKRI. Semua kebijakan pemerintah dan pembentukan tata peraturan perundangundangan, substansinya tidak boleh pula bertentangan dengan nilai-nilai yang terdapat dalam UUD 1945 sebagai hukum dasar. Pada jenjang selanjutnya, merupakan tata peraturan perundangundangan yang terdapat dalam sistem ketatanegaraan NKRI. Tata peraturan perundang-undangan tersebut terdiri dari UUD 1945; Ketetapan MPR; UndangUndang/Perppu;

Peraturan

Presiden/Peraturan

Pemerintah;

Peraturan Daerah (Perda) Provinsi; Perda Kabupaten/Kota.

Peraturan perundang-undangan yang tingkatannya lebih rendah harus berpedoman pada peraturan perundangundangan yang lebih tinggi dan substansinya juga tidak boleh bertentangan dengan peraturan perundangan yang lebih tinggi. merupakan rakyat sebagai pemegang kedaulatan tertinggi, sekaligus sebagai pelaksana kebijakan maupun tata peraturan perundang-undangan negara. Sistem penyelenggaraan pemerintahan yang berbentuk presidensial dijalankan berdasarkan sistem demokrasi pancasila, sehingga penyelenggaraan negara diwujudkan untuk kepentingan bersama seluruh masyarakat. Dengan demikian, penyelenggaraan negara dilaksanakan dari rakyat, oleh rakyat dan untuk rakyat.

\section{Kajian Mengenai LGBT}

Di Indonesia, sejak tahun 1982 mulai dibentuk komunitas untuk mengakomodasi kepentingan kaum gay, dan pada tahun 1980-an hingga tahun 
1990-an mulai bermunculan komunitas serupa bagi kaum lesbian, gay, dan transgender. Saat ini, terdapat beberapa asosiasi utama LGBT di Indonesia yang aktif melakukuan berbagai kegiatan, seperti Gaya Nusantara, Arus Pelangi dan Ardhanary Institute. Tentunya aktivitas dari berbagai asosiasi maupun kelompok LBGT di masing-masing wilayah di Indonesia mendapatkan sorotan dari masyarakat, utamanya dari pihak yang kontra terhadap aktivitas tersebut, mulai dari akademisi, para ahli hingga para pemuka agama.

Makna LGBT menurut Kamus Besar Bahasa Indonesia (KBBI) Online, didefinisikan sebagai berikut Lesbian merupakan wanita yang mencintai atau merasakan rangsangan seksual sesama jenisnya. Gay merupakan kata yang diadopsi dari bahasa inggris yang artinya homoseks, sedangkan makna homoseks diartikan sebagai hubungan seks dengan pasangan sejenis (pria dengan pria). Biseksual diartikan mempunyai sifat kedua jenis kelamin (laki-laki dan perempuan) atau tertarik kepada kedua jenis kelamin (baik kepada laki-laki maupun kepada perempuan). Transgender pengertiannya tidak ${ }_{1}$ https://id.wikipedia.org/wiki/Transgender, diunduh ditemukan dalam KBBI namun makna pada hari Jum,at tanggal 3 Pebruari 2017, Pukul 21.30 gender mengacu pada makna seksual ${ }^{2}$ http://www.kompasiana.com/fauziarizal/mengenallebih-dekat-transgender-danyang diartikan sebagai jenis kelamin. transeksual_550d32ec813311682db1e221, diunduh pada hari Jum,at tanggal 3 Pebruari 2017, Pukul 21.30 WIB yang memiliki identitas gender atau ekspresi gender yang berbeda dengan seksnya yang ditunjuk saat lahir. Orang trangender terkadang disebut sebagai orang transeksual jika ia mengnedaki bantuan medis untuk transisi dari satu seks ke seks lainnya ${ }^{1}$. Sumber lain menjelaskan bahwa transseksual adalah orang yang identitasnya gendernya berlawanan dengan jenis kelaminnya secara biologis, sedangkan transgender adalah orang yang cara berperilaku atau penampilannya tidak sesuai dengan gender pada umumnya ${ }^{2}$. Dengan demikian, transeksual dapat menyebabkan perilaku homoseks atau lesbian namun tidak dalam pengertian yang sebenarnya. Misal kaum transeksual laki-laki menyukai sesama jenis laki-laki pula bukan karena pada dasarnya homoseks, namun yang bersangkutan menyukai laki-laki lain karena mengaggap dirinya adalah perempuan. Sedangkan transgender merujuk pada penyimpangan secara fisik, misal lakilaki berpakaian seperti perempuan atau sebaliknya sehingga dapat pula mengarah 
pada operasi penggantian alat kelamin. Berdasarkan definisi tersebut dapat disimpulkan bahwa makna transgender dan transeksual pada dasarnya adalah sama, yaitu penyimpangan jenis kelamin asli baik secara biologis maupun fisik.

\section{Kajian Mengenai Pancasila}

Sebagaimana telah dipahami bahwa nilai-nilai Pancasila itu sendiri diangkat dari nilai-nilai yang ada di dalam kehidupan secara nyata bangsa Indonesia (local wisdom) yang berupa nilai-nilai adat istiadat, kebudayaan serta nilai-nilai agama yang dimiliki oleh Bangsa Indonesia sendiri sebelum membentuk negara ${ }^{3}$ Pancasila berkedudukan sebagai dasar sekaligusC. BAB III METODE PENELITIAN ideologi Negara. Makna dasar mengacu pada pedoman maupun landasan, sehingga Pancasila dijadikan sebagai pedoman dalam menjalankan seluruh sistem pemerintahan di Indonesia. Seluruh kebijakan dan peraturan yang dibuat oleh pemerintah tidak boleh bertentangan dengan nilai-nilai luhur Pancasila, sehingga Pancasila disebut sebagai sumber dari segala sumber.

Selain berkedudukan sebagai Dasar Negara, Pancasila juga berfungsi sebagai ideologi Negara Indonesia. Secara sederhana, ideologi berarti suatu gagasan yang berdasarkan pemikiran

${ }^{3}$ Kaelan, Pendidikan Pancasila (Edisi Revisi Kesepuluh),2014, Yogyakarta : Paradigma, Hlm. 124 sedalam-dalamnya dan merupakan pemikiran filsafat ${ }^{4}$. Dalam arti kata luas, istilah ideologi dipergunakan untuk segala kelompok cita-cita, nilai-nilai dasar, dan keyakinan-keyakinan yang mau dijunjung tinggi sebagai pedoman normatif. 5 Dalam konteks ideologi negara, maka Pancasila digunakan sebagai cara pandang bangsa Indonesia untuk mencapai tujuan dan cita-cita negara. Artinya, untuk mencapai tujuan dan cita-cita yang disepakati bersama dibutuhkan nilai-nilai Pancasila sebagai kerangka pemikiraannya. Pada dasarnya, ideologi Pancasila merupakan ideologi yang bersifat terbuka.

\section{Metode Pendekatan}

Metode pendekatan yang
digunakan dalam penelitian ini adalah
metode pendekatan yuridis empiris, yaitu
suatu penelitian yang menekankan pada
peraturan- peraturan atau dogma untuk
kemudian dikaitkan dengan
pelaksanaannya di masyarakat. Dengan
demikian, pengkajian data yang
digunakan utamanya menggunakan data
primer. Aspek yuridis dalam penelitian
ini dimulai dengan mengkaji Peraturan
Perundang-undangan yang berkaitan
dengan penelitian, meliputi, Undang-

${ }^{4}$ Syahrial Syarbaini, Pendidikan Pancasila di Perguruan Tinggi (Implementasi Nilai-nilai Karakter Bangsa), 2014, Jakarta : Ghalia Indonesia, Hlm.87 ${ }^{5}$ ibid 
Undang Dasar NKRI Tahun 1945 dan Undang-Undang No.1 Tahun 1974 tentang Perkawinan.

Selanjutnya, aspek empiris yang dikaji dalam penelitian ini adalah fenomena LGBT yang sedang menjadi perbincangan dan perdebatan masyarakat Indonesia, utamanya bagi generasi muda.

\section{Spesifikasi Penelitian}

Spesifikasi yang digunakan bersifat deskriptif analitis, dimana penulisan ini memaparkan, melukiskan , atau menggambarkan suatu fenomena yang terdapat di masyarakat, kemudian dikaitkan dengan peraturan perundangundangan yang berlaku, dan dengan teori-teori hukum yang relevan, sehingga diharapkan dapat menjawab pertanyaanpertanyaan yang tersaji dalam rumusan masalah yang telah penulis uraikan.

\section{Responden Penelitian}

Peneliti menetapkan beberapa Responden dalam penelitian ini dan telah dilakukan penyebaran kuesioner serta wawancara. Adapun Responden penelitian meliputi 10 Siswa kelas $\mathrm{X}$ SMK Pelita Nusantara I Semarang, 10 Siswa Kelas XI SMK N 2 Semarang, 10 Siswa Kelas XII SMA N 1 Semarang, 10 Mahasiswa Fakultas Hukum Universitas Diponegoro Semarang. Terhadap 40 Responden tersebut dilakukan penyebaran kuesioner dengan 16 pertanyaan yang bersifat tertutup.
Adapun wawancara dilakukan pada 4 Narasumber sebagai Responden penelitian, yaitu 1 orang Siswa Kelas X SMK Pelita Nusantara I Kota Semarang yaitu Cindy Putri Kamelia, 1 orang Siswa Kelas XI SMK N 2 Kota Semarang yaitu Yenni Giyantika Sari, 1 orang Siswa Kelas XII SMA N 1 Kota Semarang yaitu Vino Rahmana Putra, 1 orang Mahasiswa Fakultas Hukum Semester 5 yaitu Kirana Intan Puspita.

\section{Metode Pengumpulan data}

Jenis data yang dikumpulkan dalam penelitian ini adalah data primer dan data sekunder. Dalam penelitian ini, Peneliti terlebih dahulu mengumpulkan data primer kemudian dilengkapi melalui data sekunder. Data primer meliputi, pengisian kuesioner (melakukan penyebaran kuesioner pada 4 populasi penelitian dengan sampel SMK Pelita Nusantara I Semarang, SMK N 2 Semarang, SMA N 1 Semarang dan Fakultas Hukum Universitas Diponegoro Semarang). Wawancara (mengadakan wawancara langsung dengan menggunakan daftar pertanyaan kepada Narasumber Penelitian yang terdiri dari 4 orang dari 4 populasi penelitian).

Data sekunder merupakan data yang sudah dalam bentuk jadi atau merupakan data dari studi kepustakaan. 
Data primer yang dimaksud digunakan sebagai bahan referensi untuk menunjang keberhasilan penelitian yang terdiri dari bahan hukum primer meliputi UUD NKRI Tahun 1945 dan UU No.1 Tahun 1974 tentang Perkawinan. Bahan hukum sekunder terdiri dari buku-buku; jurnal ilmiah; hasil-hasil penelitian; berbagai hasil seminar atau kegiatan ilmiah lainnya yang berkaitan dengan fenomena LGBT di Indonesia. Bahan hukum tersier sebagai pelengkap bahan unuk menjelaskan bahan hukum primer maupun bahan hukum sekunder, meliputiD. arsip-arsip, kamus-kamus, serta website yang relevan dengan pembahasan penelitian ini yaitu mengenai peran Pancasila dan fenomena LGBT di Indonesia.

\section{Metode Penyajian Data}

Data yang telah terkumpul akan diolah melalui proses editing. Dalam proses editing juga dilakukan pembetulan data yang keliru, menambahkan data yang kurang, melengkapi data yang belum lengkap. Apabila data yang diperoleh dipandang sudah memenuhi tujuan penelitian, maka langkah selanjutnya adalah menyusun data secara sistematis untuk kemudian dilakukan analisa / pengkajian.

\section{Metode Analisis Data}
Proses analisis dalam penelitian ini akan dimulai dengan cara

mengumpulkan semua data yang ada, baik data primer maupun data sekunder. Selanjutnya terhadap data-data tersebut dilakukan proses editing dan interpretasi atau penafsiran .Metode analisis data yang digunakan adalah analisis data kualitatif , dengan metode penarikan kesimpulan menggunakan metode induktif. , yaitu metode penarikan kesimpulan yang bersifat khusus menuju penulisan yang bersifat umum.

\section{. BAB IV HASIL PENELITIAN DAN PEMBAHASAN}

\section{Respon Masyarakat Indonesia Mengenai Fenomena LGBT (Lesbian, Gay, Bisexual and Transgender) \\ Setelah Mahkamah Agung} Amerika Serikat mengesahkan UndangUndang perkawinan sesama jenis pada tahun 2015, tentunya hal tersebut sangat mempengaruhi hak dan keberadaan kaum LGBT di negara-negara dunia untuk ikut mendesak pemerintah setempat memberlakukan hal serupa termasuk kaum LGBT di Indonesia. Kaum LGBT di Indonesia melalui perwakilan organisasinya mengusulkan kepada pemerintah untuk segera merumuskan dan mengesahkan Peraturan Perundangundangan yang berkaitan dengan pemenuhan hak-hak mereka termasuk 
diperbolehkan melakukan perkawinan sejenis.

Tentunya hal tersebut menjadi perbincangan sekaligus perdebatan oleh berbagai pihak dalam menanggapi fenomena LGBT tersebut. Oleh sebagian masyarakat khususnya oleh Pemuka Agama, Akademisi maupun para Ahli dan Pakar berpendapat bahwa LGBT cenderung membawa dampak negatif khusunya bagi generasi muda. Namun tidak sedikit pula yang beranggapan bahwa kaum LGBT juga berhak mendapatkan perlakuan dan hak yang sama sebagai Warga Negara. Untuk melihat respon secara nyata dari masyarakat khususnya dari kalangan generasi muda, Peneliti melakukan penyebaran kuesioner yang terdiri dari 16 pertanyaan yang bersifat tertutup. Kuesioner tersebut ditujukan pada 4 Populasi dengan jumlah 40 Responden yang terdiri dari sampel kelas X SMK Pelita Nusantara I Semarang, Kelas XI SMK N 2 Semarang, Kelas XII SMA N 1
Semarang, dan Mahasiswa Semester 7 Fakultas Hukum Universitas Diponegoro Semarang.

Alasan pemilihan sampel tersebut didasari oleh beberapa pertimbagan. Pertama, keempat sampel tersebut mewakili masyarakat sebagai generasi muda yang dimungkinkan rentan terpengaruh LGBT. Kedua, Peneliti berasumsi bahwa siswa SMA dan Mahasiswa merupakan sasaran kaum LGBT yang dapat dipengaruhi melalui pergaulan bebas. Ketiga, Peneliti ingin mengetahui adanya perilaku LGBT di lingkungan pelajar, sehingga sampel yang ditentukan adalah dari masingmasing tempat yang berbeda dan jenjang kelas yang berbeda. Keempat, Peneliti ingin mengetahui respon generasi muda terkait fenomena LGBT yang terjadi saat ini di Indonesia, mengingat generasi muda merupakan generasi penerus bangsa. Adapun hasil penyebaran kuesioner dapat dilihat melalui tabel berikut :

Tabel 2

Hasil Pengisian Kuesioner Penelitian

\begin{tabular}{|l|l|l|l|l|l|}
\hline \multirow{2}{*}{ No. } & \multicolumn{1}{|c|}{ Pertanyaan } & \multicolumn{3}{|c|}{ Pilihan Jawaban } \\
\cline { 3 - 6 } & \multicolumn{1}{|c|}{ Ss } & \multicolumn{1}{|c|}{ S } & \multicolumn{1}{|c|}{ Rg } & \multicolumn{1}{|c|}{ Ts } \\
\hline 1. & Pengetahuan mengenai makna LGBT & $40 \%$ & $40 \%$ & - & $20 \%$ \\
\hline 2. & $\begin{array}{l}\text { LGBT sebagai akibat pergaulan bebas dan } \\
\text { pengaruh budaya asing }\end{array}$ & $42.5 \%$ & $35.5 \%$ & $17.5 \%$ & $2.5 \%$ \\
\hline 3. & $\begin{array}{l}\text { Penyebab LGB bukan karena } \\
\text { gen/keturunan namun merupakan penyakit } \\
\text { yang timbul karena faktor tertentu (misal } \\
\text { lingkungan) }\end{array}$ & $45 \%$ & $35 \%$ & $15 \%$ & $5 \%$ \\
\hline
\end{tabular}




\begin{tabular}{|c|c|c|c|c|c|}
\hline 4. & $\begin{array}{l}\text { LGBT merupakan penyimpangan seksual } \\
\text { yang bertentangan dengan nilai agama, nilai } \\
\text { kesopanan dan nilai kesusilaan }\end{array}$ & $75 \%$ & $15 \%$ & $10 \%$ & - \\
\hline 5. & $\begin{array}{l}\text { LGBT merupakan penyakit yang bisa } \\
\text { disembuhkan }\end{array}$ & $30 \%$ & $27.5 \%$ & $37.5 \%$ & $5 \%$ \\
\hline 6. & $\begin{array}{l}\text { Responden mengetahui informasi LGBT dari } \\
\text { media cetak dan elektronik }\end{array}$ & $32.5 \%$ & $62.5 \%$ & $5 \%$ & - \\
\hline 7. & $\begin{array}{l}\text { Responden melihat adanya fenomena LGBT } \\
\text { di sekitar lingkungan }\end{array}$ & $20 \%$ & $20 \%$ & $27.5 \%$ & $32.5 \%$ \\
\hline 8. & $\begin{array}{l}\text { Fenomena LGBT menjadi trend di kalangan } \\
\text { generasi muda }\end{array}$ & $15 \%$ & $17.5 \%$ & $27.5 \%$ & $40 \%$ \\
\hline 9. & $\begin{array}{l}\text { Perkawinan sesama jenis dilarang dilakukan } \\
\text { di Indonesia }\end{array}$ & $90 \%$ & $7.5 \%$ & $2.5 \%$ & - \\
\hline 10. & $\begin{array}{l}\text { Pemerintah Indonesia harus membuat } \\
\text { regulasi yang memperbolehkan perkawinan } \\
\text { sesama jenis dilakukan di Indonesia }\end{array}$ & $20 \%$ & $7.5 \%$ & $15 \%$ & $57.5 \%$ \\
\hline 11. & $\begin{array}{l}\text { Responden mengetahui ada negara lain yang } \\
\text { melegalkan perkawinan sesama jenis }\end{array}$ & $40 \%$ & $37.5 \%$ & $22.5 \%$ & - \\
\hline 12. & $\begin{array}{l}\text { Pelaku LGBT jangan dijauhi } \\
\begin{array}{l}\text { namun } \\
\text { dirangkul dan } \\
\text { disembuhkan }\end{array}\end{array}$ & $62.5 \%$ & $37.5 \%$ & - & - \\
\hline 13. & $\begin{array}{l}\text { Pelaku LGBT berhak mendapatkan } \\
\text { pengakuan dan perlindungan HAM }\end{array}$ & $52.5 \%$ & $27.5 \%$ & $10 \%$ & $10 \%$ \\
\hline 14. & $\begin{array}{l}\text { Responden mengetahui ada WNI yang } \\
\text { memutuskan pindah kewarganegaraan lain } \\
\text { dengan alasan agar dapat melakukan } \\
\text { perkawinan sesama jenis }\end{array}$ & $20 \%$ & $12.5 \%$ & $35 \%$ & $32.5 \%$ \\
\hline 15. & $\begin{array}{l}\text { LGBT bertentangan dengan Pancasila } \\
\text { sebagai Dasar Negara }\end{array}$ & $77.5 \%$ & $5 \%$ & $15 \%$ & $2.5 \%$ \\
\hline 16. & $\begin{array}{l}\text { Responden menolak keras adanya LGBT di } \\
\text { Indonesia }\end{array}$ & $72.5 \%$ & $12.5 \%$ & $5 \%$ & $10 \%$ \\
\hline
\end{tabular}

Sumber : hasil kuesioner dan data diolah Penelti

Berdasarkan tabel diatas, dapat dikaji bahwa mayoritas Responden mengetahui makna LGBT merupakan bentuk disorientasi seksual berupa menyukai sesama jenis, dimana salah satu penyebabnya akibat pergaulan bebas dan adanya pengaruh budaya asing.

Responden meyakini bahwa LGBT merupakan suatu tindakan yang bertentangan dengan berbagai nilai, meliputi nilai ketuhanan, nilai kesusilaan dan nlai kesopanan. Namun sebesar 10\% Responden masih meragukan hal tersebut. Mayoritas Responden juga berpendapat bahwa perilaku LGBT sangat bertentangan dengan Pancasila dan nilai-nilai di dalamnya, namun 2,5\% Responden mengganggap bahwa perilaku LGBT tidak bertentangan dengan Dasar Negara. Meskipun demikian, 
keseluruhan Responden sepakat bahwa pelaku LGBT pada dasanya jangan dijauhi namun dapat dilakukan pendekatan dan pembinaan agar perilaku tersebut dapat disembuhkan. Adapun respon terhadap perilaku LGBT di Indonesia, mayoritas Responden menolak keras adanya LGBT di Indonesia, namun sebesar 5 \% Responden masih meragukan hal tersebut, dan $10 \%$ Responden mendukung adanya LGBT di Indonesia. Setelah dilakukan pendalaman, alasan Responden meragukan untuk menolak LGBT di Indonesia dan setuju adanya LGBT di Indonesia atas dasar pertimbangan kesetaraan Hak Asasi Manusia yang perlu didaptkan oleh tiap Warga Negara.

Berdasarkan hasil penelitian tersebut, ternyata tidak semua Responden melihat perilaku LGBT di lingkungan sekitar. Sebesar $40 \%$ Responden melihat secara langsung adanya fenomena tersebut yang dialami oleh teman di lingkungan sekolah dan teman di lingkungan tempat tinggal. Mayoritas Responden juga paham bahwa perkawinan sesama jenis pada dasarnya tidak boleh dilakukan di Indonesia, namun berkaitan dengan pemenuhan hak kaum LGBT, sebesar 27,5 \% berpendapat bahwa pemerintah Indonesia harus membuat regulasi untuk melegalkan perkawinan sesama jenis di Indonesia.

Peneliti juga melakukan wawancara lebih mendalam kepada 4 Narasumber Penelitian untuk menanggapi perilaku LGBT di Indonesia. Adapun hasil wawancara tersebut, yaitu :

Wawancara oleh Narasumber 1 pada hari Rabu, 29 November 2016 di SMK N 2 Semarang Pukul 10.15 $\underline{\text { WIB }}$

Peneliti : "Setujukah Saudara mengenai perilaku LGBT di Indonesia ?"

Yenni Giyanika Sari (Siswa Kelas XI SMK N 2 Semarang): "Saya sangat tidak setuju adanya perilaku LGBT di Indonesia, karena LGBT bertentangan dengan nilai-nilai yang ada utamanya nilai Agama. Setahu Saya, tidak ada ajaran agama manapun yang memperbolehkan umatnya menyukai hubungan sesama jenis dan Tuhan sudah menciptkan bahwa manusia hidup untuk berpasang-pasangan dengan lawan jenisnya. LGBT patut diberantas karena hal tersebut merupakan 
penyimpangan, sehingga Pemerintah juga harus tegas untuk tidak membuat peraturan untuk mengakomodasi hakhak pelaku LGBT"

Wawancara oleh Narasumber 2 pada hari Rabu, 29 November 2016 di Rumah Responden (Jl.Jomblang Perbalan RT.07 RW.01 Semarang) Pukul 16.00 WIB

Peneliti : "Setujukah Saudara mengenai perilaku LGBT di Indonesia?"

Cindy Putri Kamelia (Siswa Kelas X SMK Pelita Nusantara I Semarang) : "Saya tidak setuju tentang LGBT. Kalau melihat perilaku seperti itu di TV atau melihat gambargambar di internet Saya jijik sendiri. Kalau mereka menyukai sesama jenis, pasti mereka tidak bisa melanjutkan keturunan. Bayangkan jika suatu saat nanti LGBT kian menyebar, maka dipastikan kehidupan bisa punah. Saya juga punya teman laki-laki tapi gaya berpakaian dan berbicaranya kemayu seperti perempuan, tapi Saya tidak menjauhi teman Saya, malah selalu saya beritahu kalau jadi cowok itu yang harus tegas, macho ndak boleh lembek".

Wawancara oleh Narasumber 3 pada hari Jum'at 9 Desember 2016 di Rumah Responden (Jl. Sinar
Kencana III No.949 C Semarang)

Pukul 19.00 WIB

Peneliti : "Setujukah Saudara mengenai perilaku LGBT di Indonesia?"

Vino Rahmana Putra (Siswa Kelas XII SMA N 1 Semarang): "Saya menolak LGBT di Indonesia, menurut Saya, LGBT sama sekali tidak ada manfaatnya. Benda saja juga ada pasanagannya, kalau ndak ada pasangannya berarti benda tersebut cacat atau rusak. Contoh ya Bu, kalau ada staker pasti dimasukin ke stop kontak biar bisa nyala, berarti manusia kan ya juga seperti itu harus berpasang-pasangan. Tuhan itu Maha Agung ndak mungkin menciptakan manusianya dari kodratnya suka sesama jenis, pasti orang-orang tersebut dipengaruhi banyak alasan, biasa saja kurangnya perhatian dari orang tua mereka atau bisa saja karena dipengaruhi teman-temannya. Belum lagi, bisa terkena penyakit kelamin termsuk HIV/AIDS",

Wawancara oleh Narasumber 4 pada hari Senin 12 Desember 2016 di Fakultas Hukum UNDIP Pukul 09.00 WIB

Peneliti : "Setujukah Saudara mengenai perilaku LGBT di Indonesia?" 
Kirana Intan Puspita (Mahasiswa

Semester 6 Fakultas Hukum

UNDIP) : "Saya sangat tidak setuju

Bu, karena sudah jelas LGBT ndak sesuai dengan kepribadian orang Indonesia, ndak sesuai dengan

Pancasila, jadi tidak ada tempat untuk

LGBT di Indonesia. Saya pernah lihat secara langsung kakak kelas Saya perempuan pacarnya juga perempuan, tapi menurut Saya perilaku seperti itu pasti bisa disembuhkan dengan dukungan orang-orang sekitarnya".

Dengan demikian dapat disimpulkan bahwa respon Narasumber adalah menolak adanya LGBT di Indonesia dengan berbagai alasan dan pertimbangan. Secara singkat, hasil kajian dapat dilihat melalui skema berikut :

\section{Skema 1}

Hasil Kajian Perilaku LGBT di Indonesia




Berdasarkan skema tersebut diatas, dapat dijelaskan bahwa:

- Perilaku

LGBT

bertentangan dengan Pancasila sebagai dasar negara Indonesia sehingga pemerintah tidak perlu membuat dan mengesahkan regulasi mengenai perkawinan sesama jenis

- Pada dasarnya, LGBT bukan merupakan perilaku yang disebabkan melalui keturunan / gen, melainkan LGBT adalah bentuk disorientasi seksual yang dapat terjadi karena berbagai faktor, misalnya faktor biologis individu, faktor keluarga, faktor sosial maupun faktor psikologi dari pribadi individu yang bersangkutan. Fakor biologis misal karena pengaruh hormone. Faktor keluarga misal pernah menerima atau melihat perlakuan kekerasan dala rumah tangga; perilaku orang tua yang mendandani anaknya dengan tidak sesuai gender sehingga membentuk karakter dan kepribadian yang berlawanan. Faktor sosial misal karena salah pergaulan di lingkungan masyrakat, sekolah maupun lingkungan tempat kerja. Faktor psikologi misal karena pengaruh trauma pernah mengalami pelecehan seksual menyimpang; maupun menganggap dirinya sendiri merasa tertekan dengan gender yang diterimanya

- LGBT tidak memberikan dampak positif bagi masyarakat maupun pelaku itu sendiri (meskipun bagi pelaku hal tersebut merupakan kepuasan nafsu duniawi) justru LGBT menimbulkan banyak dampak negatif seperti rusaknya tataran nilai dan norma yang sudah dibentuk oleh masyarakat, timbulnya berbagai penyakit kelamin menular yang dapat mematikan, serta dalam jangka waktu kedepan dapat menimbulkan punahnya manusia karena tidak dapat melanjutkan keturunan.

Paul Cameron Ph.D dari Family Research Institute melakukan penelitian bahwa penyebab munculnya dorongan berperilaku homoseksual adalah pernah disodomi waktu kecil. Selain itu penyebab lain adalah pengaruh lingkungan yang meliputi ${ }^{6}$ Sub kultur homoseksual yang tampak dan diterima secara sosial yang mengundang

${ }^{6}$ http://jurnal.selasar.com/gaya-hidup/runtuhnya-teorigen-gay, diakses pada Rabu, 8 Pebruari 2017 Pukul 19.00 WIB 
keingintahuan dan menumbuhkan rasa ingin mencoba; Pendidikan yang pro homoseksual (politisasi kurikulum oleh kaum homoseksual); Toleransi sosial dan hukum terhadap perilaku homoseksual; Adanya figure yang secara terbuka berperilaku homoseksual; Penggambaran bahwa homoseksualitas adalah perilaku yang normal dan bisa diterima

Beberapa ahli menjelaskan bahwa, perilaku LGBT bukan merupakan perilaku yang disebabkan karena gen / keturunan, melainkan karena faktorfaktor tertentu. Adapun penjelasan dari para ahli dapat dijelaskan sebagai berikut $^{7}$, Peneliti Dr.Michael Bailey dan Dr.Richard Pillard melakukan riset pada tahun 1991 terhadap pasangan saudara, yaitu kembar identik, kembar tidak identik, saudara biologis dan saudara adopsi. Riset tersebut menunjukkan terdapat $52 \%$ pasangan kembar identik dari orang gay berkembang menjadi gay, $22 \%$ pasangan kembar biasa yang mennjukkan sifat tersebut, saudara biologis memnpunyai kecenderungan 9,2\% dan saudar adopsi 10\%. Namun gen di kromosom yang membawa sifat tersebut tidak ditemukan

Dean Hamer melakukan riset pada tahun 1993 dengan meneliti 40 pasang

\footnotetext{
7 ibid
}

kakak beradik homoseksual. Hamer mangklaim bahwa satu atau beberapa gen yang diturunkan oleh ibu terletak di kromosom Xq28 dan sangat berpengaruh pada orang yang menunjukkan sifat homoseksual. Namun dari risetnya, Beliau menyatakan bahwa gen pembawa sifat homoseksual tersebut tidak ditemukan. Beliau menyatakan bahwa "Kami menerima bahwa lingkungan mempunyai peranan membentuk orientasi seksual...Homoseksualitas secara murni bukan karena genetika. Faktor-faktor lingkungan berperan. Tidak ada satu gen yang berkuasa yang menyebabkan seseorang menjadi gay...kita tidak akan dapat memprediksi siapa yang akan menjadi gay".

Prof. George Rice (Universitas Ontario Kanada) melakukan riset pada tahun 1999 dan mengadaptasi riset Hamer dengan jumlah responden 52 pasang kakak beradik homoseksual untuk melihat keberadaan empat penanda di daerah kromosom. Hasilnya menunjukkan bahwa kakak beradik tersebut tidak memperlihatkan kesamaan penanda di gen Xq28. Segala kemungkinan adanya gen Xq28 yang berpengaruh besar secara genetic terhadap timbulnya homoseksualitas dapat ditiadakan sehingga hasil penelitiantersebut tidak mendukung 
kaitan gen Xq28 yang dikatak mendasari homoseksualitas pria.

Kemudian dijelaskan pula bahwa pada dasarnya perilaku LGBT dapat disembuhkan, sebagaimana dipaparkan oleh Novi Andayani Praptiningsih (Dosen FISIP UMAHKA Jakarta) melalui disertasinya pada program Doktor Universitas Padjajaran, yang berjudul "Etnografi Komunikasi Komunitas Gay "Coming Out"". Menjelaskan bahwa "Seorang gay bisa sembuh dan menjadi laki-laki hetero karena perilaku gay bukan turunan. Dengan berbagai terapi yang tepat, penderita gay bisa kembali hidup norma. Salah satu terapinya yakni dengan pendekatan komunikasi. Terapi yang efektif dalam penelitian ini dilakukan dengan komunikasi persuasif dan pendekatan agama yang disebut sebagai spiritual and persuasive communication therapy and psikospiritual therapy"8.

\section{Fenomena LGBT di}

\section{Indonesia dan Pancasila}

Pancasila sebagai dasar negara Indonesia memiliki peran penting sebagai pedoman penyelenggaran negara. Dikaji berdasarkan stuffenbau theory (teori piramida berjenjang), Pancasila menempati posisi paling atas sebagai grudnorm (norma dasar) yang

\footnotetext{
${ }^{8}$ https://islamedia.id/hasil-penelitian-ilmiyah-lgbtbukan-keturunan-dan-dapat-disembuhkan/
}

mendasari keseluruhan peraturan perundang-undangan dibawahnya. Dengan demikian Pancasila merupakan sumber dari segala sumber hukum yang ada di Indonesia, sehingga keseluruhan peraturan perundang-undangan yang dibuat, nilai-nilainya tidak boleh bertentangan dengan sila Pancasila.

Fenomena LGBT di Indonesia yang saat ini menjadi perbincangan menimbulkan pro dan kontra di kalangan masyarakat. Dengan demikian perlu dikaji apakah fenomena LGBT sesuai dengan nilai-nilai Pancasila sebagai jati diri dan kepribadian bangsa Indonesia. Pancasila terdiri dari 5 sila yang masing-masing silanya memiliki hakikat tersendiri, namun saling berkorelasi. Tiap sila tersebut memiliki nilai-nilai yang mencerminkan sifat dan karakter bangsa Indonesia. Menanggapi fenomena LGBT yang terjadi di Indonesia,berikut ini Peneliti melakukan analisa fenomena tersebut dikaitkan dengan nilai Pancasila.

Sila Pertama, Ketuhanan Yang Maha Esa, hakikat sila pertama merupakan nilai Ketuhanan, dimana Negara Indonesia percaya dan mengakui adanya Tuhan Yang Maha Esa sebagai pencipta alam semesta beserta isinya, sehingga nilai Ketuhanan dijadikan sebagai pedoman dalam menjalankan sistem ketatanegaraan. 
Konsekuensinya, Negara ikut campur dalam urusan agama. Salah satu pengaturan yang diberlakukan yaitu mengenai mekanisme terjadinya perkawinan di Indonesia yang diatur dalam UU No.1 Tahun 1974 tentang Perkawinan. Pada Pasal 1 dijelaskan bahwa "Perkawinan ialah ikatan bathin antara seorang pria dengan seorang wanita sebagai suami isteri dengan tujuan membentuk keluarga (rumah tangga) yang bahagia dan kekal berdasarkan Ketuhanan Yang Maha Esa". Selanjutnya dalam Pasal 3 ayat (1) dijelaskan bahwa "Pada azasnya dalam suatu perkawinan seorang pria hanya boleh mempunyai seorang isteri. Seorang wanita hanya boleh mempunyai seorang suami”. Menurut KBBI online, makna suami merupakan pri yang menjadi pasangan hidup resmi seorang wanita, sedangkan makna istri adalah wanita (perempuan) yang telah menikah atau yang bersuami.

Berdasarkan pengaturan dan makna tersebut, jelas bahwa perilaku LGBT (Lesbian, Gay, Bisexual and Transgender) merupakan perilaku yang bertentangan dengan nilai Ketuhanan. Pada dasarnya perilaku LGBT merupakan perilaku ketertarikan seksual dengan sesama jenis yaitu antara pria dengan pria dan wanita dengan wanita. Dengan demkian, pelaku LGBT tidak mempercayai bahwa Tuhan hanya menciptakan makhluknya untuk berpasang-pasangan dengan lawan jenis untuk membentuk keluarga yang sah dan melanjutkan keturunan. Pelaku LGBT juga tidak dapat melakukan perkawinan sesama jenis di Indonesia karena sudah jelas bahwa syarat dilakukannya perkawinan yaitu antara pria dan wanita.

Sila Kedua, Kemanusiaan yang Adil dan Beradab, manusia dalam kehidupan sehari-hari menjalankan dua peran sekaligus, yaitu sebagai makhluk individu dan sebagai makhluk sosial. Dalam menjalankan perannya tersebut, manusia wajib menjunjung tinggi harkat dan martabat dirinya sendiri dan sesama manusia lain tanpa melakukan bentuk diskriminasi sebagaimana dijelaskan dalam Pasal $28 \mathrm{~J}$ ayat (1) UUD NKRI Tahun 1945 bahwa "Setiap manusia wajib menghormati hak asasi manusia orang lain dalam tertib kehidupan bermasyarakat, berbagsa dan bernegara”. Selanjutnya pada Pasal 28 J ayat (2) dijelaskan bahwa "Dalam menjalankan hak dan kebebasannya, setiap orang wajib tunduk kepada pembatasan yang ditetapkan dengan undang-undang dengan maksud sematamata untuk menjamin pengakuan serta penghormatan atas hak dan kebebasan orang lain dan untuk memenuhi 
tuntutan yang adil sesuai dengan perimbangan moral, nilai-nilai agama, keamanan dan ketertiban umum dalam suatu masyarakat demokratis".

Kedua aturan tersebut menjelaskan bahwa tiap individu memiliki hak asasi, namun hak asasi yang dimiliki juga ada batasannya untuk menghargai hak asasi orang lain dengan memperhatikan norma dan nilai yang ada di masyarakat. Terkait dengan perilaku LGBT, pada dasarnya Peneliti setuju jika pelaku LGBT berhak menerima hak asasi seperti hak hidup, hak bersosialisasi maupun hak untuk bebas dari perlakuan diskriminasi. Namun kenyataanya di masyarakat, fenomena tersebut mayoritas belum diterima oleh masyarakat Indonesia sehingga mengganggu keamanan dan ketertiban umum di masyarakat karena bertentangan dengan moral dan nilai agama. Dengan demkian apabila keberadaan kaum LGBT menyebabkan terganggunga ketertiban umum, maka bertentangan dengan hak asasi kepentingan umum sehingga bertentangan dengan sila kedua. Namun tetap pada koridor bahwa pelaku LGBT tidak boleh dijauhi maupun diperlakukan dengan kekerasan, justru pelaku LGBT harus dirangkul agar bisa disembuhkan layaknya manusia normal pada umumnya.
Sila Ketiga, Persatuan Indonesia, Indonesia merupakan bangsa yang multikultur dari berbagai aspek, namun kemultikulturan tersebut tidak mengarahkan pada perpecahan namun dari yang berbeda tersebut dapat menjadi satu kesatuan bangsa yang utuh. Selain memberlakukan norma hukum, bangsa Indonesia juga menerapkan berbagai norma yang dibuat dan dikehendaki sendiri oleh masyarakat setempat. Salah satunya yaitu norma kesopanan dan norma kesusilaan. Norma tersebut bersifat tidak tertulis namun ditaati dan dilaksanakan sebagai kaidah untuk mengatur masyarakat. Dalam norma kesopanan maupun norma kesusilaan menghendaki bahwa hubungan pasangan yang sah merupakan hubungan dalam ikatan perkawinan antara laki-laki dan perempuan, jika belum terlaksananya perkawinan maka hubungan seksual antara laki-laki dan perempuan tidak boleh dilaksanakan atau dianggap tabu. Terlebih apabila hubungan tersebut dilakukan sesama jenis. Pada dasarnya, masyarakat mutlak beranggapan bahwa pasangan adalah antara laki-laki dan perempuan, sehingga jika adanya hubungan sesama jenis maka masyarakat mengaggap bahwa perilaku tersebut tidak sesuai 
dengan norma yang ada dan bertetangan dengan nilai agama.

Apabila perilaku LGBT terjadi di suatu masyarakat yang menjunjung tinggi berbagai norma dan nilai agama, maka dipastikan akan terjadi pertentangan dan mengganggu ketertiban umum, sehingga dapat mengarahkan pada disintegrasi (perpecahan). Apabila mayoritas masyarakat Indonesia tidak menghendaki adanya LGBT, namun LGBT haknya diakomodasi melalui perkawinan sesama jenis, maka terjadi pemberontakan yang menyebabkan masyarakat Indonesia terpecah belah. Dengan demkian fenomena LGBT rentan dimungkinkan menyebabkan disintegrasi antar masyarakat sehingga bertentangan dengan nilai persatuan.

Sila Keempat, Kerakyatan yang Dipimpin oleh Hikmat Kebijaksanaan dalam permusyawaratan Perwakilan. Hakikat sila keempat merupakan makna demokratis atau musyawarah. Masyarakat Indonesia diarahkan menjadi manusia yang bijaksana dalam menetukan suatu keputusan secara bersama dengan kesepakatan bersama, baik di kehidupan bermasyarakat, berbagsa maupun bernegara. Dengan demikian ukuran kesepakatan adalah ukuran masyarakat secara mayoritas demi kepentingan umum / bersama.
Dikaitkan dengan fenomena LGBT, apabila mayoritas masyarakat Indonesia tidak menghendaki adanya LGBT dan menganggap bahwa perilaku LGBT merupakan perilaku menyimpang, maka fenomena LGBT bertentangan dengan sila keempat, sehingga pemerintah tidak boleh melegalkan perkawinan sesama jenis di Indonesia karena bertentangan dengan kehendak masyarakat secara umum.

Sila Kelima, Keadilan Sosial bagi Seluruh Rakyat Indonesia. Hakikat sila kelima merupakan makna adil. Pengertian adil yang dimaksud adalah adil bagi kepentingan umum. Sila kelima berkaitan dengan keempat sila sebelumnya, sehingga makna adil tidak diartikan adil menurut tiap individu, karena sifatnya relatif dan berbeda-beda makna antar satu individu dengan individu lainnya. Dengan demkian ukuran untuk menetukan makna adil adalah adil bagi kepentingan masyarakat secara luas. Jika perilaku LGBT dianggap sebagai perilaku yang menyimpang dan mengganggu tatanan sosial di masyarakat, maka fenomena LGBT bertentangan dengan sila kelima.

Berdasarkan kajian tersebut, maka dapat disimpulkan bahwa fenomena LGBT di Indonesia bertentangan dengan nilai-nilai Pancasila, sehingga peran Pancasila adalah sebagai filter 
untuk menolak segala bentuk legalisasi bagi kaum LGBT di Indonesia, termasuk Pemerintah Indonesia wajib menolak untuk mengesahkan regulasi mengenai perkawinan sesama jenis. Disisi lain, dampak negatif dari perilaku LGBT dapat dijelaskan melalui tabel berikut:

\section{Tabel 3}

\section{Dampak Perilaku LGBT bagi Individu}

\begin{tabular}{|c|c|c|c|}
\hline No. & Dampak & Penjelasan & Sumber \\
\hline 1. & $\begin{array}{l}\text { Merusak } \\
\text { tatanan } \\
\text { noma dan } \\
\text { nilai dalam } \\
\text { masyarakat }\end{array}$ & $\begin{array}{l}\text { Jika LGBT diperbolehkan di } \\
\text { Indonesia, maka akan merusak } \\
\text { tatanan norma yang sudah dibuat } \\
\text { dan dikendaki oleh masyarakat } \\
\text { Indonesia, selain itu Indonesia } \\
\text { merupakan negara ketuhanan } \\
\text { dimana tidak ada satu ajaran } \\
\text { agama manapun yang } \\
\text { memperbolehkan hubungan } \\
\text { seksual sesama jenis }\end{array}$ & $\begin{array}{l}\text { misal dalam agama islam } \\
\text { dijelaskan dalam Al-Qur'an } \\
\text { Surah Al-A'raaf Ayat } 81 \\
\text { "Sesungguhnya kamu } \\
\text { mendatangi lelaki untuk } \\
\text { melepaskan nafsumu (kepada } \\
\text { mereka) bukan kepada wanita, } \\
\text { malah kamu ini adalah kaum } \\
\text { yang melampaui batas" }\end{array}$ \\
\hline 2. & $\begin{array}{l}\text { Timbulnya } \\
\text { berbagai } \\
\text { penyakit } \\
\text { kelamin } \\
\text { yang } \\
\text { menular }\end{array}$ & $\begin{array}{l}\text { Pergaulan bebas sesama jenis } \\
\text { dapat menyebabkan berbagai } \\
\text { penyakit kelamin menular yang } \\
\text { berbahaya, termasuk penyakit } \\
\text { AIDS yang berdampak pada } \\
\text { kematian. WHO menjelaskan } \\
\text { bahwa kaum gay dan } \\
\text { transgender memiliki resiko } 20 \\
\text { kali lebih besar tertular penyakit } \\
\text { HIV/AIDS dibandingkan dengan } \\
\text { populasi normal. }\end{array}$ & $\begin{array}{l}\text { http://doktersehat.com/kaum- } \\
\text { gay-dan-transgender-mereka- } \\
\text { yang-paling-beresiko-terkena- } \\
\text { hivaids/ }\end{array}$ \\
\hline 3. & $\begin{array}{l}\text { Punahnya } \\
\text { manusia } \\
\text { karena tidak } \\
\text { bisa } \\
\text { melanjutkan } \\
\text { keturunan }\end{array}$ & $\begin{array}{l}\text { Menurut konsep biologi, } \\
\text { perkawinan merupakan proses } \\
\text { terjadinya pertemuan antara sel } \\
\text { telur dari wanita dan sel sperma } \\
\text { dari pria, sehingga jika terjadi } \\
\text { perkawinan sejenis maka tidak } \\
\text { bisa dihasilkan keturunan }\end{array}$ & $\begin{array}{l}\text { http://www.kompasiana.com/da } \\
\text { rwonogurukita/lgbt-ancam- } \\
\text { punahnya-manusia- } \\
\text { manusia_570323d2ce7e616205 } \\
\underline{90 \mathrm{ca} 80}\end{array}$ \\
\hline
\end{tabular}

Berdasarkan tabel tersebut dapat dilihat bahwa perilaku LGBT tidak membawa dampak negatif bagi manusia, justru sebaliknya perilaku LGBT membawa banyak dampak negatif. Dengan demkian perilaku LGBT harus diberantas dan para pelaku wajib dirangkul untuk dibina dan disembuhkan.

Sebagai bahan perbandingan, ada beberapa negara dunia yang sampai saat ini juga tidak melakukan legalisasi terhadap perkawinan sejenis, yaitu di Benua Afrika, seluruh Negara bagian 
menolak adanya LGBT dan legalisasi perkawinan sejenis. Kemudian Benua Amerika meliputi, Amerika Utara (Bermuda, Meksiko, Saint Pierre et Miquelon)Seluruh negara bagian Amerika Tengah, seluruh negara bagian Kepulauan Karibia (kecuali Puerto Riko), Amerika Selatan kecuali (Argentina, Guyana Prancis, Kolombia, Uruguay), Benua Asia meliputi seluruh negara Asia Tengah, seluruh negara bagian Asia Barat, Asia Timur, Asia Selatan, Asia tenggara. Benua Eropa meliputi Eropa Utara (kecuali Finlandia,Norwegia dan Swedia), Eropa Barat (negara yang menolak meliputi Guernesey, jersey, Monako dan Pulau Man), seluruh negara bagian Eropa Tengah, seluruh negara bagian Eropa Timur, Eropa Selatan (kecuali Portugal dan Spanyol).

\section{E. BAB V SIMPULAN}

Berdasarkan pembahasan terhadap rumusan masalah penelitian, maka dapat disimpulkan sebagai berikut. Pertama, Penelitian yang dilakukan terhadap 4 populasi penelitian meliputi 40 Responden yang melakukan pengisian kuesioner dan 4 Narasumber yang telah dilakukan wawancara mengenai fenomena LGBT di Indoneia menunjukkan respon bahwa mayoritas menolak adanya LGBT di Indonesia karena bertentangan dengan berbagai nilai dan norma di masyarakat. Berdasarkan beberapa penelitian yang dilakukan oleh para ahli menunjukkan bahwa perilaku LGBT bukan merupakan perilaku yang disebabkan karena faktor gen / keturunan, melainkan dapat dipengaruhi oleh faktor-faktor lain seperti faktor biologis, faktor keluarga, faktor sosial dan faktor psikologis. Meskipun melakukan penolakan terhadap LGBT, namun pelaku LGBT jangan dijauhi maupun dibenci, melainkan harus didukung dan dibina agar sembuh dan kembali norma seperti manusia pada umumnya, karena pada dasarnya LGBT merupakan penyakit perilaku seksual menyimpang yang dapat disembuhkan dengan bantuan dan dukungan berbagai pihak.

Kedua, Berdasarkan hasil analisa dan kajian, LGBT bertentangan dengan nilai-nilai Pancasila, yaitu bertentangan dengan nilai Ketuhanan, Nilai Kemanusiaan, Nilai Persatuan, Nilai Kerakyatan dan Nilai Keadilan. Pada dasarnya perilaku LGBT tidak membawa manfaat apapun, justru sebaliknya, menimbulkan berbagai dampak negatif seperti rusaknya tataran norma dan nilai di masyarakat, terjangkitnya berbagai penyakit seksual menular yang berbahaya dan mematikan, serta dalam jangka waktu panjang dapat menyebabkan punahnya manusia karena 
tidak dapat melanjutkan keturunan. Jurnal Antropologi Indonesia, Vol.30 No.1, Dengan demkian, perilaku LGBT Halaman 1-6 bertentangan dengan kepribadian dan jati ,http://www.tappdf.com/read/131gay-dandiri bangsa Indonesia. Ibarat suatu lesbian-indonesia-serta-gagasanbarang dapat berfungsi dan digunakan nasionalismel, diakses Pada Kamis, 9 apabila ada pasangannya, demikian pula Pebruari2017 Pukul 20.00 WIB dengan manusia yang telah diciptakan oleh Tuhan untuk berpasang-pasangan dan saling melengkapi.

\section{DAFTAR PUSTAKA}

\section{$\underline{\text { A. Buku-buku }}$}

Husaini, Adian. 2015. LGBT di Indonesia (Perkmebangan dan Solusinya). Jakarta : Insists

Kaelan. 2014. Pendidikan Pancasila (Edisi Revisi Kesepuluh). Yogyakarta : Paradigma

Soekanto,Soerjono dan Sri Mahmudji ,2012. Penelitian Hukum Normatif Suatu Tinjauan Persada Singkat, Jakarta : PT.Raja Grafindo

Syarbaini, Syahrial. 2014. Pendidikan

Pancasila di Perguruan Tinggi

(Implementasi Nilainilai Karakter Bangsa). Jakarta :

Ghalia Indonesia

\section{Disertasi dan Jurnal Ilmiah}

Praptiningsih, Novi Andayani, 2016.

Etnografi Komunikasi Komunitas Gay

“Coming Out". Disertasi Doktor pada

Fakultas Ilmu Komunikasi Universitas

Padjajaran, Bandung

Boellstroff, Tom. 2006. Gay dan Lesbian Indonesia serta Gagasan Nasionalisme.

\section{Peraturan Perundang-undangan}

Undang-Undang Dasar NKRI Tahun 1945

Undang-Undang No.1 Tahun 1974 tentang Perkawinan

\section{$\underline{\text { Website }}$}

https://id.wikipedia.org/wiki/Hak_LGBT_di Indonesia, diunduh pada hari Selasa 7 Pebruari 2017, Pukul 19.00 WIB https://id.wikipedia.org/wiki/Hak_LGBT_me nurut_negara, diunduh pada hari Selasa 7 Pebruari 2017, Pukul 19.15 WIB http://www.seputarpengetahuan.com/2015/1 0/5-pengertian-globalisasi-menurut-paraahli-lengkap.html, diunduh pada hari Jum'at tanggal 3 Pebruari 2017 Pukul 04.00 https://id.wikipedia.org/wiki/Globalisasi, diunduh pada hari Jum'at tanggal 3 Pebruari 2017 Pukul 05.00

https://id.wikipedia.org/wiki/Globalisasi, diunduh pada hari Jum'at tanggal 3 Pebruari 2017 Pukul 05.00 https://id.wikipedia.org/wiki/Transgender, diunduh pada hari Jum, at tanggal 3 Pebruari 2017 , Pukul 21.30 WIB

http://www.kompasiana.com/fauziarizal/men genal-lebih-dekat-transgender-dan transeksual_550d32ec813311682db1e221, diunduh pada hari Jum,at tanggal 3 Pebruari 2017 , Pukul 21.30 WIB

http://jurnal.selasar.com/gayahidup/runtuhnya-teori-gen-gay, diakses pada Rabu, 8 Pebruari 2017 Pukul 19.00 WIB http://www.bbc.com/indonesia/majalah/2015 /05/150516_majalahain_luksemburg_gay, diakses pada Senin, 6 Maret 2017 Pukul 10.00

WIB. 